\title{
Bazı Ekmeklik Buğday Genotiplerinin (Triticum aestivum L.) Doğal Yağış Koşullarındaki Verim ve Kalite Parametrelerinin Değerlendirilmesi
}

\author{
*Hüsnü AKTAŞ ${ }^{1}$ Mehmet KARAMAN ${ }^{2}$ Erol ORAL ${ }^{1}$ Enver KENDAL ${ }^{1}$ Sertaç TEKDAL ${ }^{2}$ \\ ${ }^{1}$ Mardin Artuklu Üniversitesi, Kızıltepe Meslek Yüksek Okulu, Mardin \\ ${ }^{2}$ GAP Uluslararası Tarımsal Araştırma ve Eğitim Merkezi Müdürlüğü, Diyarbakır \\ Sorumlu yazar e-posta (Corresponding author; e-mail):h_aktas47@hotmail.com
}

\section{Öz}

Çalışma 2011-12 ve 2012-13 yetiştirme sezonlarında, Hazro/Diyarbakır ekolojik koşullarında yazlık gelişme tabiatıı ileri kademedeki 20 ekmeklik buğday genotipi ile tescilli 5 çeşidin yağışa dayalı şartlarda verim ve bazı kalite özelliklerinin araştırılması amacıyla yürütülmüştür. İki yıllık birleştirilmiş varyans analiz sonuçlarına göre incelenen tüm özellikler için genotipler arasındaki fark istatistiki olarak $(P<0.05)$ önemli bulunmuştur. Birinci yılda G21 (392 kg/da), ikinci yılda ise Dinç çeşidi (610 kg/da) en yüksek tane verimine sahip genotipler olurken, G4, G8 ve G5 (Dinç) her iki yılda da yüksek ve aynı zamanda benzer tane verimi performansına sahip genotipler olmuş, G19 ve G21 genotipleri ise ortalamadan yüksek tane verimine sahip olmalarına rağmen her iki yılda farklı performansa sahip olarak kaydedilmiştir. Birinci yılda, G9 bin tane ağırlığı ve hektolitre için, G21 genotipi tane verimi için (TV), G3 sedimantasyon için, G4 protein için, ikinci yılda ise G14 genotipi başakta tane ağırığı, başakta tane sayısı, G12 sedimantasyon için, G15 ve G2 bin tane ağırlığı bakımından en yüksek performansa sahip genotipler olmuştur. Basit korelasyon analizi sonuçlarına göre, metre karede başak sayısı ile tane verimi; protein oranı ile sedimantasyon arasında pozitif; tane verimi ile protein oranı arasında da negatif ve istatistiki olarak önemli korelasyonlar tespit edilmiştir. Çalışma sonucunda G21 genotipi hem tane verimi hem de kalite özellikleri için üstün özelliklere sahip olduğu için çeşit tescili için ümitvar bir genotip olarak saptanırken, buğday ıslah programlarında yüksek tane verimine sahip çeşitlerin tespitinde birim alandaki başak sayısının seleksiyon kriteri olarak kullanılabileceği tespit edilmiştir.

Anahtar kelimeler: Buğday, verim bileşenleri, kalite

\section{Evaluation of Some Bread Wheat Genotypes of Yield and Quality Parameters Under Rainfall Condition}

\begin{abstract}
This study was performed to investigate yield and quality traits of advanced spring bread wheat genotypes and five cultivars (Triticum aestivum L.) in rainfall condition of the Hazro/Diyarbakır during 2011-12 and 201213 growing seasons. According to combined variance analysis statistically significant differences $(P<0.05$ or $\mathrm{P}<0.01$ ) were determined for all examined traits of genotypes in two years. According to results of analysis G21 in first year and G5 in second year had a highest grain yield. G4, G8 and G5 (Dinç) were determined as higher yielding genotypes, also they showed similar performance for both two years, while G19 and G21 had a high yield but different peformance, so they could be suitable for specific areas. Results indicated that G9 was the best for 1000 kernel weight and test weight and G21, G3, G4 were the best genotypes for grain yield, sedimentation, protein content respectively in the first year; G14, G12 and G15 were classified as best for grain weight in spike, sedimentation and 1000 kernel weight respectively in second year. Positive and high correlation were determined between number of spike in square meter and grain yield; also between protein content and sedimentation; negative correlation between grain yield and protein content. According to results of present study, G21 was determined as candidate for registration as cultivar because of it's high grain and appreciate quality traits, also number of spike in square meter could be used as parameter to select high yielding genotypes in breeding programs.
\end{abstract}

Key Words: Wheat, yield component, quality traits

DOI: 10.21566/tarbitderg.323601 


\section{Giriş}

E kmeklik buğday (Triticum aestivum L.) tahıllar içerisinde en yüksek ekim alanı, üretim oranına sahip tahıllardan birisi olduğu gibi, insan beslenmesinde çok önemli bir yere sahiptir (Kün ve ark. 1995). Türkiye'deki toplam buğday ekim alanı 7.2 milyon ha, tane verimi ortalaması ise $270 \mathrm{~kg} /$ da olarak bildirilmektedir (TUİK 2015). Buna karşın Güneydoğu Anadolu Bölgesinin buğday ekim alanı 1.3 milyon ha olarak bildirilmektedir (TUİK 2015). Buğday üretimi çeşit, çevresel faktörler ve agronomik uygulamalar tarafından etkilenmektedir. Bir ülke içerisinde, bölgelerdeki agroekolojik ve klimatik koşullar, yıllara göre düşen yağış miktarı gibi çevresel faktörler, gübre kullanımı, toprak verimliliği, kullanılan çeşitlerin adaptasyon yetenekleri buğday bitkisindeki verimliliği etkileyen faktörlere örnek olarak verilebilir (Mut ve ark. 2015). Özellikle yağışa dayalı yapılan buğday üretimi miktarı yıl içerisindeki toplam yağış miktarı aynı zamanda yağışın mevsimler içerisindeki dağılışının değişkenlik göstermesi nedeniyle yıldan yıla farklılıklar arz etmektedir.

Türkiye'deki ve Güneydoğu Anadolu Bölgesindeki buğday üretiminin çoğunun yağışa dayalı şartlarda yapılması bu anlamda verimliliği ve toplam buğday üretimin miktarını kısıtlamaktadır (Kılıç ve ark. 2010). Güneydoğu Anadolu Bölgesindeki buğday üreticileri artezyen kuyularından elde ettikleri yer altı suyu ile sulama yoluna gitmekte ve yıl içerisindeki yetersiz ve düzensiz yağışın oluşturduğu etkileri ortadan kaldırmaya çalışmaktadırlar. Oysaki yeraltı sularının uzun vadede tarımda kullanılması sürdürülebilir olmadığı gibi, çok sayıda olumsuz çevresel sorunların oluşumuna da neden olmaktadır. Bu nedenle yağışa dayalı şartlarda kabul edilebilir verime oranına sahip, yağışa dayalı şartlara uygun buğday genotiplerinin belirlenmesi ve geliştirilmesi hayati bir öneme sahiptir. Yağışa dayalı şartlardaki buğday üretiminde tane veriminin yanında, buğday tanesinin kalite özellikleri de etkilenmektedir. Örneğin, yağışa dayalı şartlardaki üretimde bin tane ağırlığı düşük olmakta, bu da buğday tanesinden elde edilen un miktarının düşüşüne sebep olmakta ve un sanayisi de bu durumdan etkilenmektedir (Aktaş 2014).

Buğday ıslah programlarında yağışa dayalı şartlara uygun veya limitli su koşullarına tolerant, hastalık ve zararlılara dayanıklı, kalite parametrelerince istenilen özelliklere sahip buğday çeşitlerinin geliştirilmesi amaçlanmaktadır. Bu amaçla, melezleme ile elde edilmiş saf buğday hatları veya uluslararası kuruluşlardan sağlanan buğday genotipleri ilk önce mikro denemelerde (tek lokasyon ve tek tekerrürlü), daha sonra makro denemelerde (çok lokasyon, çok tekerrürlü denemler) yağışa dayalı ve sulu koşullarda değerlendirilmektedir. Farklı lokasyon veya yıllarda değerlendirilen genotipler, verim, verim bileşenleri, kalite parametreleri ile alakalı veriler ANOVA, basit korelasyon gibi istatistiki metotlar ve stabilite analizine tabi tutulup çeşit tescili için ümitvar olan buğday genotipleri belirlenmektedir. (Kendal 2016).

$\mathrm{Bu}$ çalışma Diyarbakır koşullarında 201112 ve 2012-13 buğday yetiştirme sezonlarında doğal yağış koşullarına uygun genotiplerin belirlenmesi amacıyla Güneydoğu Anadolu Ekmeklik Buğday Islah Projesi kapsamında bölge verim denemesi aşamasına gelmiş genotipler kullanılarak yürütülmüştür. Çalışmada kullanılan genotiplere ait tane verimi, verim komponentlerinin değerlendirilerek tescile aday genotiplerin belirlenmesi amaçlanmıştır.

\section{Materyal ve Yöntem}

$\mathrm{Bu}$ çalışmada, materyal olarak CIMMYT (Uluslararası Buğday ve Mısır Geliştirme Merkezi, Meksika) orjinli 20 ileri kademedeki ekmeklik buğday hattı ve Güneydoğu Anadolu Bölgesinde yoğun ekim alanına sahip 5 ekmeklik buğday çeşidi kullanılmıştır (Çizelge 1). Denemeler, Tesadüf Blokları Deseninde ve 4 tekrarlamalı olarak düzenlenmiştir. Denemeler Diyarbakır'ın Hazro ilçesinde yağışa dayalı şartlarda 2011-12 ve 2012-13 yetiştirme sezonlarında yürütülmüştür. Denemede parseller 6 sıra ve her sıranın arası $20 \mathrm{~cm}$, parsel uzunlukları 5 metre, toplam ekim alanı $6 \mathrm{~m}^{2}$ olarak ayarlanmış, ekim metrekareye 450 tohum düşecek şekilde deneme mibzeri ile yapılmıştır. Denemelerde ekimle beraber 6 $\mathrm{kg} / \mathrm{da}$ saf azot (N) ve $6 \mathrm{~kg} / \mathrm{da}$ saf fosfor $\left(\mathrm{P}_{2} \mathrm{O}_{5}\right)$ ve kardeşlenme döneminde $6 \mathrm{~kg} / \mathrm{da}$ saf azot (N) olacak şekilde gübreleme yapılmıştır. Denemenin yürütüldüğü deneme alanına ait topraklarının $\mathrm{pH}=7.8$, organik madde oranı= $\% 1.12$ ve kireç oranı $\left(\mathrm{CaCO}_{3}\right)=\% 10.5 \mathrm{~kg} / \mathrm{da}$ olarak tespit edilmiştir. Denemenin yürütüldüğü birinci yıl yetiştirme sezonunda alınan toplam yağış miktarı $305 \mathrm{~mm}$ ve ikinci yılda ise 430 $\mathrm{mm}$ olarak gerçekleşmiştir. Ortalama sıcaklık değerleri ilk ve ikinci yıllarda sırayla $11.9^{\circ} \mathrm{C}$ ve $10.9^{\circ} \mathrm{C}$ olarak kaydedilmiştir. (Anonim 2014). 
Aktaş ve ark. "Bazı Ekmeklik Buğday Genotiplerinin (Triticum aestivum L.) Doğal Yağış Koşullarındaki Verim ve Kalite Parametrelerinin Değerlendirilmesi"

Çalışmadaki tüm tarımsal özellikler için ölçüm ve gözlemler Pask ve ark. (2012)'nin kullandığı yöntemler kullanılarak yapılmıştır. Başakta tane sayısı, başakta tane ağırlığı her parselden rastgele seçilen 10 başaktaki ölçümlerle; metre karede başak sayısı her parselde ortadaki iki sırada 1 metre uzunlukta varolan başakların sayılması ve daha sonra elde edilen değerin formülüze edilmesiyle; tane verimi, tüm parselin hasat edilmesiyle elde edilin

Çizelge 1. Araştırmada kullanılan buğday genotipleri

Table 1. The list of wheat genotypes used in this study

\begin{tabular}{|c|c|c|}
\hline Sembol & Pedigri/Seleksiyon Geçmişi & Orijin \\
\hline G1 & $\begin{array}{l}\text { Bav92//Irena/Kauz/3/Huites/4/Doll } \\
\text { Cmss05b00188s-099y-099m-099y-099ztm-18wgy-0b }\end{array}$ & CIMMYT \\
\hline G2 & $\begin{array}{l}\text { Gk Aron/Ag Seco 7846//2180/4/2*Mılan/Kauz//Prınıa/3/Bav92 } \\
\text { Cmsa05y00954t-040m-040ztp0y-040ztm-040sy-12ztm-01y-0b }\end{array}$ & CIMMYT \\
\hline G3 & $\begin{array}{l}\text { Attıla/Bav92//Pastor/3/Attıla*2/Pbw65 } \\
\text { Cmsa04m00070s-040ztb-040zty-040ztm-040sy-13ztm-04y-0b }\end{array}$ & CIMMYT \\
\hline G4 & $\begin{array}{l}\text { Cunnıngham/4/Snı/Trap\#1/3/Kauz*2/Trap//Kauz } \\
\text { Cmsa04m00088s-040ztb-040zty-040ztm-040sy-3ztm-01y-0b }\end{array}$ & CIMMYT \\
\hline G5 & Dinç & CIMMYT \\
\hline G6 & $\begin{array}{l}\text { Whear/Kronstad F2004 } \\
\text { Cgss04y00106s-099y-099m-099y-099m-13wgy-0b }\end{array}$ & CIMMYT \\
\hline G7 & $\begin{array}{l}\text { Pfau/Serı.1b//Amad/3/Inqalab91*2/Kukuna/4/Wbll1*2/Kuruku } \\
\text { Cgss04b00024t-099y-099ztm-099y-099m-26wgy-0b }\end{array}$ & CIMMYT \\
\hline G8 & $\begin{array}{l}\text { Pauraque } \\
\text { Cgss01b00055t-099y-099m-099m-099y-099m-35wgy-0b }\end{array}$ & CIMMYT \\
\hline G9 & $\begin{array}{l}\text { Wbll1*2/Bramblıng } \\
\text { Cgss01b00062t-099y-099m-099m-099y-099m-39wgy-0b }\end{array}$ & CIMMYT \\
\hline G10 & Pehlivan & TÜRKIYE \\
\hline G11 & $\begin{array}{l}\text { Metso/Whear } \\
\text { Cmss04m00886s-0y-099ztm-099y-099m-5wgy-0b }\end{array}$ & CIMMYT \\
\hline G12 & $\begin{array}{l}\text { Sokoll//Prl/2*Pastor } \\
\text { Cmsa04y00608s-150ztp0y-010m-010sy-3m-02y-0b }\end{array}$ & CIMMYT \\
\hline G13 & $\begin{array}{l}\text { Sokoll/Excalıbur } \\
\text { Cmsa04y00612s-25ztp0y-010m-010sy-4m-03y-0b }\end{array}$ & CIMMYT \\
\hline G14 & $\begin{array}{l}\text { Vorobey } \\
\text { Cmss96y02555s-040y-020m-050sy-020sy-27m-0y }\end{array}$ & CIMMYT \\
\hline G15 & Cemre & CIMMYT \\
\hline G16 & $\begin{array}{l}\text { Ega Bonnıe Rock/4/Mılan/Kauz//Prınıa/3/Bav92 } \\
\text { Cmsa06y00125s-040ztp0y-040ztm-040sy-2ztm-01y-0b }\end{array}$ & CIMMYT \\
\hline G17 & $\begin{array}{l}\text { Ega Bonnıe Rock/4/Mılan/Kauz//Prınıa/3/Bav } 92 \\
\text { Cmsa06y00125s-040ztp0y-040ztm-040sy-2ztm-02y-0b }\end{array}$ & CIMMYT \\
\hline G18 & $\begin{array}{l}\text { H45/4/Krıchauff/Fınsı/3/Ures/Prl//Bav92 } \\
\text { Cmsa06m00501s-040ztm-040zty-11ztm-0y-0b }\end{array}$ & CIMMYT \\
\hline G19 & $\begin{array}{l}\mathrm{Pvn} / / \mathrm{Car} 422 / \mathrm{Ana} / 5 / \text { Bow/Crow//Buc/Pvn/3/Yr/4/Trap\#1/6/Worrakatta } \\
\text { /2*Pastor/7/Prl/2*Pastor Cmsa06y00821t-040ztm-040ztp0y-040ztm-040p0y- } \\
\text { 16ztm-0y-0b }\end{array}$ & CIMMYT \\
\hline G20 & Sagitario & ITALYA \\
\hline G21 & $\begin{array}{l}\text { Bwd-4/3/Attıla/Bav92//Pastor/4/Attıla*2/Pbw65 } \\
\text { Cmsa06y00896t-040ztm-040ztp0y-040ztm-040sy-15ztm-0y-0b }\end{array}$ & CIMMYT \\
\hline G22 & $\begin{array}{l}\text { Hello//Sunco/2*Pastor } \\
\text { Cmsa06y00492s-040zty-040ztm-040sy-6ztm-0y-0b }\end{array}$ & CIMMYT \\
\hline G23 & $\begin{array}{l}\text { Altar 84/Ae.Squarrosa (221)//3*Borl95/3/ Ures/Jun//Kauz/4/Wbll1/5/Mılan/S87230// } \\
\text { Bav92 } \\
\text { Cmss06b00201s-0y-099ztm-099y-099m-14wgy-0b }\end{array}$ & CIMMYT \\
\hline G24 & $\begin{array}{l}\text { Rolf07*2/5/Fct/3/Gov/Az//Mus/4/Dove/Buc } \\
\text { Cmss06y01061t-099topm-099y-099ztm-099y-0fus-7wgy-0b }\end{array}$ & CIMMYT \\
\hline G25 & Adana 99 & TÜRKIYE \\
\hline
\end{tabular}


tohumun tartılmasıyla; 1000 tane ağırlığı, hasadı yapılan deneme parsellerinden elde edilen tohumların hassas tartıda tartılmasıyla g/1000 tane olarak; hektolitre ağırlığı, 1 It'lik ölçek ile tartılarak bulunan değerin 100 ile çarpılmasıyla; bitki boyu, her parselden rastgele seçilen 10 bitkide toprak yüzeyinden ana saptaki başağın ucuna kadarki uzunluğun (kılçıklar hariç) cm cinsinden ölçülmesiyle belirlenmiştir. Protein analizi AACC 39-10 metoduna göre Near Infrared model 6500 cihazı kullanılarak (Anonim 1990) metoduna göre ve Zeleny Sedimantasyon analizi ise ICC-No. 115 (Anonim 1982) metoduna göre yapılmıştır.

Elde edilen verilerin, varyans analizi (ANOVA) ve incelenen özellikler arasındaki korelasyon analizi JUMP istatistik paket programı kullanılarak yapılmış; ortalamalar arasındaki farklılıklar ise LSD testi ile $(p<0.01$ ve $p<0.05)$ incelenmiştir (Gomez ve Gomez 1984).

\section{Bulgular ve Tartışma}

İki yıllık veriler birleşik analize tabi tutulmuş ve ANOVA analizi sonuçlarına göre yıllar arasındaki fark, başakta tane sayısı dışında, incelenen tüm özellikler için 0.01 veya 0.05 düzeyinde istatistiki olarak önemli bulunmuştur. Genotip ortalamaları arasındaki farklar ise incelenen tüm özellikler için 0.01 düzeyinde istatistiki olarak önemli olarak saptanırken, yı ${ }^{*}$ çeşit interaksiyonları tane verimi (TV), başakta tane sayısı (BŞTS) özellikleri dışında istatistiki olarak ( 0.01 veya 0.05 düzeyinde) önemli olarak bulunmuştur (Çizelge 2). Birçok araştırmacı farklı yıl veya çevrelerde yürütülen adaptasyon çalışmalarında genotip, yıl veya çevre ortalamaları arasında istatistiki olarak önemli farklılıklar tespit ettiklerini, oluşan varyasyonun büyük bir kısmının yıllar veya çevrelerden kaynaklandığını bildirmişlerdir (Anıl 2000; Başer ve ark. 2001 ). Bu çalışmada da benzer sonuçlar elde edilmiş olup, kareler ortalaması bakımından tüm özellikler için en yüksek değere yıl faktörünün sahip olduğu, dolayısıyla oluşan varyasyonun daha çok yıllardan kaynaklandığını göstermektedir.

\section{Tane Verimi}

İki yıllık birleştirilmiş varyans analizi sonuçlarına göre buğday genotiplerinin tane verimi ortalaması arasındaki fark istatistiki olarak önemli bulunurken, genotiplerin tane verimi 346 (G24) ile 498 kg/da (G5) arasında değişmiş, ortalama tane verimi ise $408 \mathrm{~kg} / \mathrm{da}$ olarak gerçekleşmiştir (Çizelge 4). G3, G5, G6, G7, G8, G9, G14, G17, G18, G21 ve G22'e ait tane verimleri ortalamanın üstünde, diğer genotiplerin tane verimleri ise ortalamadan düşük olmuştur. Birinci yılda genotiplerin tane verimi $257 \mathrm{~kg} / \mathrm{da}$ ( G4) ile 392 kg/da (G21) arasında değişmiş, ortalama 307 kg/da olarak kaydedilmiştir. G5,G6, G7 ve G8 ortalamanın üstünde tane verimine sahip iken, diğer genotipler ise ortalamanın altında tane verimine sahip genotipler olarak belirlenmiştir. İkinci yılda tane verimi ortalaması 509 kg/da olarak kaydedilirken, en yüksek tane verimi $610 \mathrm{~kg} / \mathrm{da}$ ile (G5) Dinç çeşidinden elde edilmiştir. G8, G9, G13, G14, G19, G21, G22 ve G23 genotipleri ortalamadan daha yüksek tane verimi değerlerine sahip genotipler olarak tespit edilmiştir (Çizelge 4). Yıllar arasındaki tane verimi ortalamaları incelendiğinde ikinci yıldaki tane verimi ortalaması (509 kg/da), birinci yıldaki ortalama verime (307 kg/da) göre daha yüksek olmuştur. Bu sonuç, ikinci yıldaki toplam yağış miktarının daha yüksek olmasından kaynaklanmaktadır. Birçok araştırmacı tarafından, tane veriminin çok genle idare edilen bir karakter olduğu, aynı zamanda yıl, lokasyon, yağış miktarı gibi birçok faktörden etkilendiği bildirilmiştir (Kaydan ve Yağmur 2008; Mut ve ark. 2005 ).

\section{Başakta Tane Ağırığı}

Birinci yetiştirme sezonunda genotiplerin ortalama başakta tane ağırlığı $2.14 \mathrm{~g}$ olarak kaydedilmiş, en düşük değer 1.70 gr (G1, $\mathrm{G} 2$ ), en yüksek ise $2.50 \mathrm{gr}$ (G11) olarak tespit edilmiştir. G5, G7, G8, G9, G1, G12, G16, G17, G18, G19, G20, G21 ve G23 ortalamadan daha yüksek değere sahipken, diğer genotipler ortalamanın altında değerlere sahip genotipler olmuştur. Ayçiçek ve Yıldırım (2006) Erzurum koşullarında yürüttükleri çalışmada, buğday genotiplerinin başakta tane ağırlığının 1.52 ile $2.34 \mathrm{~g}$ arasında değiştiğini bildirmişlerdir. İkinci yıl verileri incelendiğinde başakta tane ağırlığı değerlerinin daha yüksek olduğu görülmektedir. Bu sonuç, söz konusu yetiştirme sezonunda düşen yağış miktarının daha yüksek olmasından kaynaklanmaktadır. İkinci yıldaki başakta tane ağırlığı 1.95 ile 3.09 g arasında değişmiş, ortalama ise $2.48 \mathrm{~g}$ olarak kaydedilmiştir. İki yılın birleştirilmiş analiz sonuçlarına göre başakta tane ağırığı bakımından en yüksek değerler sırasıyla G24 (2.65 g), G16 (2.53 g), G12 (2.52 g) ve G5 $(2.51 \mathrm{~g})$ genotiplerinden elde edilmiş, ortalama ise $2.31 \mathrm{~g}$ olarak kaydedilmiştir.

\section{Başakta Tane Sayısı}

Varyans analiz sonuçlarına göre, her iki yetiştirme sezonunda da genotiplerin başakta tane sayısı değerleri arasındaki fark istatistiki olarak önemli bulunmuştur. Birinci yılda 

Verim ve Kalite Parametrelerinin Değerlendirilmesi"

genotiplerin ortalama başakta tane sayısı 42.21 tane/başak, ikinci yılda ise 52.34 tane/ başak olarak kaydedilmiştir. Birinci yılda en düşük başakta tane sayısı değerleri G9 (32.38 tane/başak), G10 (32.50 tane/başak) ve G15 (33.50 tane/başak) genotiplerinden, en yüksek değerler ise G5 (48 tane / başak), G4 (47.88 tane/başak), G14 (47.75 tane/başak) ve G17 (46.75 tane / başak) genotiplerinden elde edilmiştir. İkinci yılda en yüksek başakta tane sayısı değerleri G4 (59.50 tane/başak), G8 (58.38 tane/başak) ve G14 (59.50 tane/başak) genotiplerinden elde edilmiştir.

Birleştirilmiş analiz sonuçlarına göre genotipler arasındaki fark istatistiki olarak önemli bulunurken, genotiplerin ortalama başakta tane sayısı değeri 47.27 tane/başak olarak gerçekleşmiş, en yüksek değer G4 (53.69 tane/başak) ve G14 (53.63 tane/başak) genotiplerinden elde edilmiştir. Başakta tane sayısı, tane veriminin artırılmasında çok önemli bir faktör olduğu, yoğun ıslah çalışmaları ile başakta tane sayısı artırıldığı, ama tane iriliği veya bin tane ağırlığında ise azalma olduğu bildirilmektedir (Lopes ve ark. 2015). Ayrıca, başak uzunluğu ve genişliği ve başakçık sıklığı, buğday genotiplerinin başaktaki tane sayısının potansiyelini etkilediği belirtilmektedir (Ubaidullah ve ark. 2006).

\section{Bin Tane Ağırlığı (g)}

Bin tane ağırlığı, genotipik bir özellik olması yanında çevresel faktörlerden etkilenen bir karakterdir (Rahman ve ark. 2009). Birinci yetiştirme sezonunda ortalama bin tane ağırlığı değeri 28.87 g olarak kaydedilirken, en düşük bin tane ağırlığı değeri G4 (24.81 g), en yüksek değer ise $\mathrm{G} 21(33.75 \mathrm{~g})$ genotiplerinden elde edilmiştir. G9, G10, G18, G23 ve G25 yüksek bin tane ağırlığına sahip genotipler olarak tespit edilmiştir. Normal koşullarda bin tane ağırlığı yüksek ve düşük olan bir buğday çeşidi, uygun koşullarda yetiştirildiğinde, genotipik olarak yüksek bin tane ağırlığına sahip çeşit daha yüksek bir değere sahip olur, fakat sıcaklık, kuraklık, hastalık gibi stres koşullarında tersi sonuçlar elde edilebilir (Çölkesen ve ark. 2002). Aktaş (2014) Pehlivan çeşidinin (G10) yüksek bin tane ağırlığına sahip olduğunu, fakat sıcaklık stresinin yaşadığı, vejetasyon süresinin daha kısa olduğu alanlarda bu çeşidin bin tane ağırlığında düşüş olduğunu bildirmiştir. Yağış miktarının yüksek olduğu ikinci yetiştirme sezonunda en düşük bin ağırlığı 35.25 g ile G1 genotipinde, en yüksek değer ise 39.63 $\mathrm{g}$ ile $\mathrm{G} 15$ genotipinden elde edilmiş, genotiplerin ortalama bin tane ağırlığı ise $36.20 \mathrm{~g}$ olarak kaydedilmiştir. İkinci yıldaki bin tane ağırlığı değerlerinin daha yüksek olması bu sezonda düşen yağış miktarının daha yüksek olması ile ilişkilendirilebilir.

\section{Hektolitre Ağırlığı (kg/hl)}

Birinci yetiştirme sezonunda genotiplerin ortalama hektolitre ağırlığı 78.09 kg/hl, ikinci senede ise $82.65 \mathrm{~kg} / \mathrm{hl}$, her iki yılın ortalaması ise 80.37 kg/hl olarak kaydedilmiştir. Birinci yetiştirme sezonunda en yüksek değerler G10 (81.84 kg/ hl), G25 (81.64 kg/hl), G9 (80.83 kg/hl) ve G23 $(80.62 \mathrm{~kg} / \mathrm{hl})$ genotiplerinden, ikinci senede ise G8 (84.70 kg/hl), G10 (84.25 kg/hl), G21 (84.38 $\mathrm{kg} / \mathrm{hl})$ ve G25 (84.18 kg/hl) en yüksek değerlere sahip genotipler olmuştur. Hektolitre ağırlığı, tanedeki karın boşluğu, tanenin buruşukluğu gibi tane yapısının genel özelliklerinden etkilenmekle beraber limitli su koşullarında hektolitre ağırlığında düşüşler olmaktadır (Aguirre ve ark. 2002).

\section{Protein Oranı (\%)}

Birinci yetiştirme sezonunda genotiplerin ortalama protein oranı \% 15.43 iken, ikinci senede ise \%13.46 olarak gerçekleşmiştir. Birinci yılda yağış miktarının düşük olması, tane verimi, bin tane ağırlığı ve hektolitre ağırlığının düşük olmasına neden olurken, protein oranının da artmasında etkili olmuştur. Tanedeki protein oranı ile tane verimi arasında ters bir orantı olduğu, aynı zamanda yüksek tane verimi potansiyeline sahip genotiplerin protein oranı başta olmak üzere birçok kalite parametresi bakımından düşük performansa sahip oldukları bildirilmektedir. (Kaya ve Akçura 2014). Birinci yılda en yüksek protein oranı G15 (\% 16.80), G5 (\% 16.53) ve G20 (\% 16.66) genotiplerinden elde edilirken, ikinci yılda ise G17 (\% 14.20), G2 (\% 13.94), G15 (\% 13.98) ve G24 (\% 13.94) genotiplerinden elde edilmiştir. G15 ve G2 genotipleri her iki sezonda da en yüksek protein oranına sahip genotipler olmuştur. Buğday genotiplerinin protein oranı bakımından mevcut potansiyelinin belirlenmesi ve ıslah programlarında seleksiyon işleminin sulu veya yağış miktarının yüksek olduğu alanlarda yapılmasının daha isabetli olacağını belirtilmektedir (Akram ve ark. 2010).

\section{Zeleny Sedimantasyon Değeri (ml)}

Birinci yetiştirme sezonunda genotiplerin ortalama sedimantasyon değeri 39.54 ml iken, ikinci senede ise $33.85 \mathrm{ml}$ olarak gerçekleşmiştir. Birçok çalışmada sedimantasyon parametresinin kalıtım derecesinin, protein oranı gibi diğer kalite parametrelerine göre yüksek olduğu farklı 

Condition"

çevrelerden daha az etkilendiğini bildirilmiştir (Altınbaş ve ark. 2004). Birinci yılda en yüksek sedimantasyon değeri G4 (55.00 ml), G13(50.50 $\mathrm{ml})$ ve $\mathrm{G} 12(47.25 \mathrm{ml})$ genotiplerinden elde edilirken, ikinci yılda ise G12 (42.75 ml), G14 $(41.50 \mathrm{ml})$ ve $\mathrm{G} 18(40.50 \mathrm{ml})$ genotiplerinden elde edilmiştir. G12 her iki sezonda da en yüksek sedimantasyon değerine sahip genotip olurken, G23 her iki sezonda da en düşük değere sahip genotip olarak kaydedilmiştir.

\section{Bitki Boyu (cm)}

Birinci yılda ortalama bitki boyu $82.36 \mathrm{~cm}$, ikinci yılda ise $90.60 \mathrm{~cm}$ olarak gerçekleşmiştir. Su stresinin yaşandığı, yağışa dayalı şartlarda bitki boyu yüksek olan buğday genotipleri genel olarak daha yüksek tane verimine sahip olup, buğday ıslah programlarında kurak ve yarı kurak alanlar için seleksiyon yapılırken bitki boyu seleksiyon kriteri olarak kullanılmaktadır (Akçura ve ark. 2011). Yağışın düşük olduğu birinci yetiştirme sezonunda ortalamanın üstünde bitki boyuna sahip G7 (95) ve G21 (90 cm) yüksek tane verimine sahip genotipler olmuşlardır. Buna karşın, daha düşük bitki boyuna sahip olan $\mathrm{G} 5(75 \mathrm{~cm}), \mathrm{G} 8$ (80 $\mathrm{cm})$ ve $\mathrm{G} 17(75 \mathrm{~cm})$ genotipleri de yüksek tane verimine sahip genotipler olarak kaydedilmiştir. Birçok araştırmacı kısa boyluluk genlerine sahip CIMMYT orjinli buğday genotiplerinin yüksek tane verimi potansiyeline sahip oldukları bildirilmiştir (Guedira ve ark. 2010). İkinci yetiştirme sezonunda bitki boyu $82.5 \mathrm{~cm}$ (G15 ve G20) ile $101.3 \mathrm{~cm}$ (G4 ve G7) değişmiş ve genel olarak ortalamadan daha düşük bitki boyuna sahip G5, G8, G14, G19 ve G22 genotipleri yüksek tane verimine sahip genotipler olarak kaydedilmiştir.

Çizelge 2. Buğday hat ve çeşitlerinde iki yıllık birleştirilmiş varyans analiz sonuçları (kareler ortalamaları) Table 2. Averaged two years results of analysis variance for bread wheat lines and cultivars (mean squares)

\begin{tabular}{|c|c|c|c|c|c|c|c|c|c|c|c|}
\hline \multicolumn{12}{|c|}{ Kareler Ortalaması } \\
\hline Kaynaklar & Sd & TV & BŞTA & MKBS & BŞTS & BB & BŞGS & BTA & HL & PRT & SDS \\
\hline Yıl & 1 & $2042423^{* *}$ & $5.90^{* *}$ & $23818^{*}$ & $5134^{* *}$ & $512^{* *}$ & 0.08 öd & $2694^{* *}$ & $1035^{* *}$ & $214^{* *}$ & $1619^{* *}$ \\
\hline $\begin{array}{l}\text { Tek [Yıl] \& } \\
\text { Rnd }\end{array}$ & 6 & 12853 * & 0.05 öd & $4587^{*}$ & 21.8 öd & 21.58 öd & 1.62 öd & 1.1 öd & 4.50 öd & 1.11 öd & 26.82 öd \\
\hline Genotip & 24 & $9386^{* *}$ & $0.30^{* *}$ & $5921^{\star *}$ & $172^{\star *}$ & $299^{* *}$ & $57^{* *}$ & $30^{* *}$ & $24.62^{\star *}$ & $2.39^{* *}$ & $198^{* *}$ \\
\hline YIl x Çesit & 24 & 3573 öd & $0.25^{\star *}$ & $1165^{*}$ & 14.2 öd & $37^{* *}$ & $0.62^{*}$ & $14.7^{\star \star}$ & $8.96^{\star \star}$ & $1.52^{\star \star}$ & $57^{* *}$ \\
\hline CV (\%) & & 13.4 & 8.8 & 10.1 & 8.1 & 1.99 & 0.6 & 3.8 & 1.1 & 4.2 & 5.7 \\
\hline
\end{tabular}

Sd: Serbestlik derecesi; TV: Tane verimi; BŞTA: Başak ağırığı; MKBS: Metrekarede başak sayısı; BBS: Başakta başakçık sayısı; BŞTS: Başakta tane sayısı; BB: Bitki boyu; HL: Hektolitre ağırlığı; öd: istatistiki olarak önemli değil; *: İstatistiki olarak 0.05 düzeyinde önemli; ${ }^{* *}$ : İstatistiki olarak 0.01 düzeyinde önemli;

Sd: Freedoom value; TV: Grain yield; BAĞ: Grain weight in spike; MKBS: Numbre of spike in $m^{2}$; BBS: Number of spikeliet pers pike; BŞGS: Heading days; BTA: 1000 kernel weight; HL: Test weight; PRT: Grain protein content; SDS: Zeleny dimentation content; *: Significant at level 0.05; **: Significant at level 0.01, öd: not significant

Çizelge 3. İki yıllık ortalama veriler üzerinden incelenen özellikler için korelasyon analizi sonuçları Table 3. Results of correlation analysis for averaged two years data of examined traits

\begin{tabular}{|c|c|c|c|c|c|c|c|c|c|}
\hline & TV & MKBS & BŞTA & BTS & SDS & PRT & BTA & $\mathrm{HL}$ & BB \\
\hline TV & 1 & & & & & & & & \\
\hline MKBS & $0,67^{* *}$ & 1 & & & & & & & \\
\hline BSTA & 0,11 öd & $-0,22$ öd & 1 & & & & & & \\
\hline BTS & 0,27 öd & $-0,44^{*}$ & $0,45^{*}$ & 1 & & & & & \\
\hline SDS & 0,05 öd & $-0,08$ öd & 0,13 öd & 0,33 öd & 1 & & & & \\
\hline PRT & $-0,32$ öd & $-0,07$ öd & $-0,10$ öd & 0,03 öd & $0,54^{* *}$ & 1 & & & \\
\hline BTA & $-0,24$ öd & $-0,19$ öd & $-0,15$ öd & $-0,49^{*}$ & $-0,33$ öd & $-0,43^{*}$ & 1 & & \\
\hline $\mathrm{HL}$ & $-0,03$ öd & 0,02 öd & $-0,23$ öd & $-0,38^{*}$ & $-0,63^{* *}$ & $-0,52^{* *}$ & $0,70^{* *}$ & 1 & \\
\hline BB & 0,17 öd & $-0,03$ öd & 0,12 öd & 0,05öd & 0,27 öd & $-0,27$ öd & 0,32 öd & $-0,10$ öd & 1 \\
\hline BGS & 0,01 öd & 0,17 öd & $-0,51^{* *}$ & $-0,36$ öd & $-0,36$ öd & $-0,12$ öd & 0,28 öd & $0,41^{*}$ & $-0,25$ öd \\
\hline
\end{tabular}

TV: Tane verimi; BAĞ: Başak ağırlığı; MKBS: Metrekarede başak sayısı; BŞTS: Başakta tane sayısı; BB: Bitki boyu; HL: Hektolitre ağırlığı

*: İstatistiki olarak 0.05 düzeyinde önemli; **: İstatistiki olarak 0.01 düzeyinde önemli; öd: istatistiki olarak önemli değil; TV: Grain yield; BŞTA: Grain weight in spike; MKBS: Numbre of spike in $m^{2}$; BŞGS: Heading days; BTA: 1000 kernel weight; HL: Test weight; PRT: Grain protein content; SDS: Zeleny sedimentation content

*: Significant at level 0.05; **: Significant at level 0.01, öd: not significant 


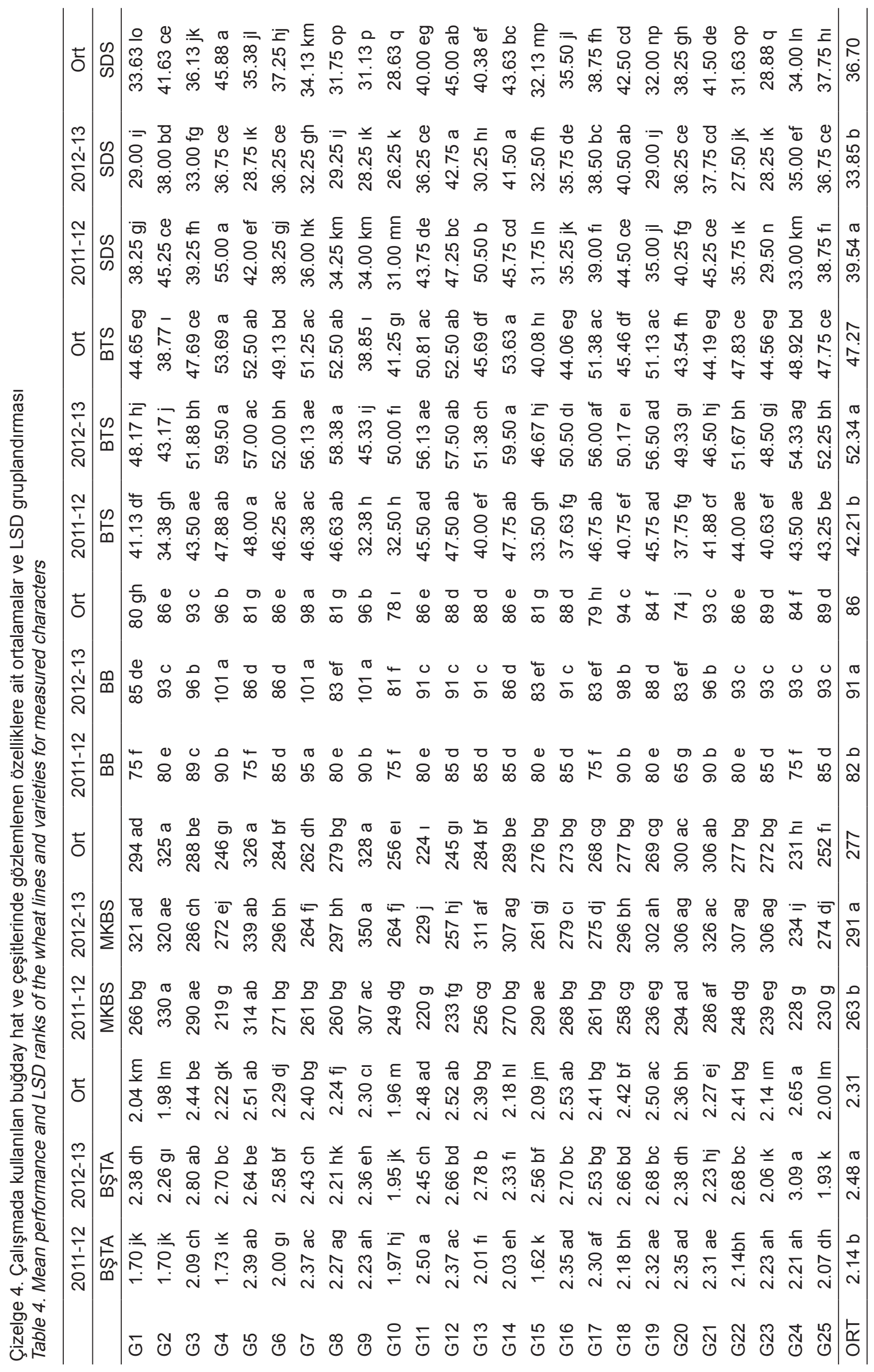




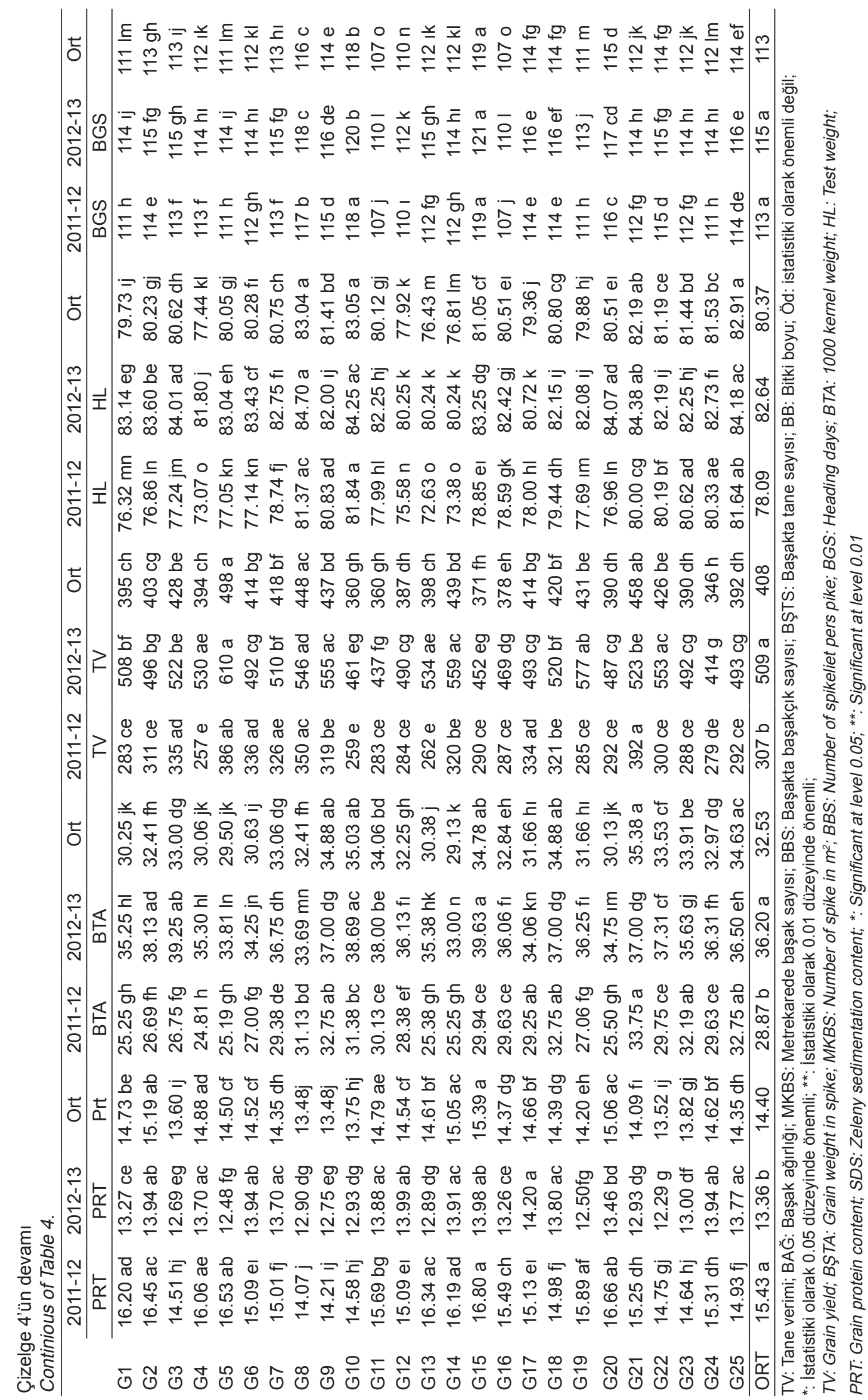


Aktaş ve ark. "Bazı Ekmeklik Buğday Genotiplerinin (Triticum aestivum L.) Doğal Yağış Koşullarındaki Verim ve Kalite Parametrelerinin Değerlendirilmesi"

\section{Başaklanma Gün Sayısı}

Erkenciliğin göstergesi olan başaklanma gün sayısı özellikle su stresinin yaşandığı, vejetasyon süresinin kısa olduğu alanlar ile ikinci ürün mısır veya pamuktan sonra geç ekime uygun buğday genotiplerinin seçiminde önemli bir kriterdir (Kılıç ve ark. 2010). Alınan sonuçlara göre birinci yılda başaklanma gün sayısı 111 gün (G1, G5, G19 ve G24) ile 118.75 gün (G15) arasında değişmiş, ortalama değer ise 112.69 gün olarak kaydedilmiştir. İkinci yılda ise 110 gün (G11, G16) ile 121 gün (G15) arasında değişmiş, ortalama başaklanma gün sayısı ise 115 gün olarak belirlenmiştir.

İncelenen Özellikler Arasındaki İlişkilerin Korelasyon Analizi ile Yorumlanması

İki yıllık ortalama veriler üzerinden yapılan korelasyon analizi sonuçları Çizelge 3.'te verilmiştir. Bu sonuçlara göre tane verimi ile metrekarede başak sayısı arasında yüksek ve istatistiki olarak önemli bir korelasyon tespit edilmiştir. Tane verimi ile diğer özellikler arasında istatistiki olarak önemli bir korelasyon tespit edilmezken, başakta tane sayısı ile tane verimi arasında pozitif ve önemsiz, ama diğer özelliklere nazaran daha yüksek bir korelasyon, tane verimi ile protein oranı arasında da negatif ve istatistiki olarak önemsiz bir korelasyon tespit edilmiştir. Yoğun ıslah çalışmaları sonucunda buğdayda tane verimi artarken, protein oranında ise bir düşüş olduğu birçok araştırmacı tarafından bildirilmektedir (Lopes ve ark. 2015; Akram ve ark. 2010). Birim alanda başak sayısının arttıkça tane veriminin arttığı ve metre karede başak sayısının yüksek tane verimine sahip buğday çeşitlerinin geliştirilmesinde seleksiyon kriteri olarak kullanılması gerektiği bildirilmektedir (Kaydan ve ark. 2008). Metre karede başak sayısı ile başakta tane sayısı; bin tane ağırlığı ile başakta tane sayısı özellikleri arasında negatif, başakta tane sayısı ile başakta tane sayısı arasında da ise pozitif ve istatistiki olarak önemli bir korelasyon bulunmuştur. Protein oranı ile sedimantasyon; hektolitre ağırlığı ile bin tane ağırlığı arasında pozitif ve istatistiki olarak önemli korelasyonlar tespit edilmiştir. Buğday ıslah programlarında başak uzunluğu ile beraber fertil başakçık sayısının ve başakta tane sayısının artırılması yolu ile tane veriminin artırılması hedeflendiği (Alam et al. 2013), genel olarak tanedeki protein oran ile kalite özellikleri arasında da yüksek bir korelasyon olduğu (Akram ve ark. 2010; Altınbaş ve ark. 2004; Kaya ve Akçura 2014) rapor edilmiştir

\section{Sonuç}

Yapılan iki yıllık çalışma sonucunda, G21 çeşit olarak tescil edilecek özelliklere sahip olduğu, Dinç çeşidinin (G5) bölge koşullarında yetiştirilmesinin tane veriminin artışına katkı yapacağı, G4, G12 ve G24 genotiplerinin tane verimlerinin ortalamadan düşük olmasına rağmen, protein oranı ve sedimantasyon özellikleri için üstün değerlere sahip olduğu ve bu genotiplerin de kalite artırma amacıyla genitör olarak kullanılabilecek potansiyele sahip oldukları, ayrıca yüksek verimli buğday çeşitlerinin geliştirilmesi amacıyla yürütülen buğday ıslah çalışmalarında metre karede başak sayısının seleksiyon kriteri olarak kullanılabileceği tespit edilmiştir.

\section{Teşekkür}

Bu çalışma Tarımsal Araştırmalar Genel Müdürlüğü'ne bağlı GAP Uluslararası Tarımsal Araştırma Enstitüsü Müdürlüğünün desteği ile Ülkesel Buğday Islah Programı kapsamında yürütülmüştür.

\section{Kaynaklar}

Aguirre A., Badiali O., Cantarero M., Leon A., Ribotta P. and Rubido O., 2002. Relationship of test weight and kernel properties to milling and baking quality in Argentine triticales. Cereal Research Communications 30: 1-2 pp. 203208)

Akçura M., Partigoç F. and Kaya Y., 2011. Evaluating of drought stress tolerance based on selection indices in Turkish bread wheat landraces. The Journal of Animal \& Plant Sciences 21(4): 700-709

Akram H.M., Sattar A., Ali,A. and Nadeem M.A., 2010. Agro-physiological performance of wheat genotypes under moisture stress conditions. J. Agric. Research 48(3):361-369

Aktaş H., 2014. Investigation of quality stability and micro elements content of some bread wheat varieties in southeast Anatolia region conditions. Mustafa Kemal University, Field Crop Department. PhD Thesis. pp. 269.

Alam N., Akhter M., Hossain, M. and Zaman, R., 2013. Performance of different genotypes of wheat (Triticum aestivum L.) in heat stress conditions. International Journal of Biosciences 3 (8): 295-306

Altınbaş M., Tosun M., Yüce S., Konak C., Köse E. ve Can R.A., 2004. Ekmeklik buğdayda ( $T$. aestivum L.) tane verimi ve bazı kalite özellikleri üzerinde genotip ve lokasyon etkileri. Ege Üniversitesi, Ziraat Fakültesi Dergisi 41 (1): 65-74. 
Aktaş et al. "Evaluation of Some Bread Wheat Genotypes of Yield and Quality Parameters Under Rainfall Condition"

Anonim., 1982. ICC-Standart No:115/1. 1982. International Association for Cereal Chemistry

Anonim., 1990. AACC Approved Methods of the American Association of Cereal Chemist. 1990, USA

Anonim., 2014. https://www.mgm.gov.tr/ (Erişim Tarihi: 24.07. 2014)

Ayçiçek, M. ve Yıldırım, T., 2006. Bazı makarnalık buğday (Triticum turgidum var. durum L.) çeşitlerinin Erzurum koşullarındaki verim yetenekleri. Fırat Üniv. Fen ve Müh. Bil. Dergisi 18(2):151-157.

Başer N., Öztürk İ., Avcı, R. ve Kahraman T., 2001. Trakya Bölgesi'nde Yetiştirilen Buğday Çeşitlerinin Verim, Kalite ve Diğer Bazı Özellikleri ile Buğday Tarımının Önemli Sorunları. Türkiye IV. Tarla Bitkileri Kongresi, 17-21 Eylül, Tekirdağ, 1: 63-68.

Çölkesen M., Öktem A., Engin A. A. ve Öktem G., 2002. Bazı arpa çeşitlerinin (Hordeum vulgare L.) Kahramanmaraş ve Şanlıurfa koşullarında tarımsal ve kalite özelliklerinin belirlenmesi. KSÜ Fen ve Mühendislik Dergisi 5(2): 47-56

Gomez K. and Gomez A.A., 1984. Statistical Procedures for Agricultural Research, $2^{\text {nd }}$ Edition. John Wiley and Sons. New York. 680 $\mathrm{pp}$

Guedira M., Brown-Guedira G., Van Sanford D., Sneller C., Souza E. and Marshall D., 2010. Distribution of $R$ ht genes in modern and historic winter wheat cultivar from the Eastern and Central USA. Crop Science 50:18111822.

Kaya Y. and Akçura, M., 2014. Effects of genotype and environment on grain yield and quality traits in bread wheat ( $T$. aestivum L.). Food Sci. Technol, Campinas 34(2): 386-393

Kaydan D. ve Yağmur M., 2008. Van Ekolojik Koşullarında Bazı Ekmeklik Buğday (Triticum aestivum L.) Çeşitlerinin Verim ve Verim Öğeleri Üzerine Bir Araştırma. Tarım Bilimleri Dergisi 14 (4): 350-358
Kendal E., 2016. GGE Biplot Analysis of MultiEnvironment Yield Trials in Barley (Hordeum vulgare L.) Cultivars. Ekin Journal of Crop Breeding and Genetics 2(1):90-99

Kılıç H. ve Akçura M. and Aktaş, H., 2010. Assessment of parametric and nonparametric methods for selecting stable and adapted durum wheat genotypes in multienvironments. Not. Bot. Hort. Agrobot. ClujNapoca 38: 271-279.

Kün E., Avcı M., Uzunlu V. ve Zencirci N., 1995. Serin İklim Tahılları Tüketim Projeksiyonları ve Üretim Hedefleri. TMMOB Ziraat Mühendisleri Odası, 4. Türkiye Ziraat Mühendisleri Teknik Kongresi 9- 13 Ocak, s. 417-429

Lopes S.M., El-Basyoni İ., Baenziger P.S., Singh S., Royo C., Ozbek K., Aktaş H., Ozer E., Ozdemir F., Manickavelu A., Ban T. and Vikram,P., 2015. Exploiting genetic diversity from landraces in wheat breeding for adaptation to climate change. Journal of Experimental Botany 66(12): 3477-3486

Mut Z., Aydın N, Özcan H. ve Bayramoğlu O., 2005. Orta Karadeniz Bölgesi'nde Ekmeklik Buğday (Triticum aestivum L.) Genotiplerinin Verim ve Bazı Kalite Özelliklerinin Belirlenmesi. GOP Üniversitesi Zir. Fak. Dergisi 22 (2): 85-93.

Pask A.J.D., Pietragalla J, Mullan D.M. and Reynolds M.P., 2012. Physiological Breeding II: A Field Guide to Wheat Phenotyping. Mexico City, Mexico: CIMMYT.

Rahman M.M., Hossain A., Hakim M.A., Kabir M.R. and Shah M.M.R., 2009. Performance of wheat genotypes under optimum and late sowing condition. International Journal of Sustain Crop Production 4(6): 34-39.

TÜIK, 2015. Statistical databases. http://tuikapp. tuik.gov.tr/bitkiselapp/bitkisel.zl (Erişim Tarihi: 21.09. 2015)

Ubaidullah, Raziuddin, Mohammad, Hafeezullah T, Ali S. and Nassimi A.W., 2006. Screening of wheat (Triticum aestivum L.) genotypes for some important traits against natural terminal heat stress. Pakistan Journal of Biological Science 9: 2069 - 2075. 